\title{
Dissolved and Suspended Particulate Metals in Setiu River Basin, Terengganu, Malaysia
}

(Logam Terlarut dan Partikulat Terampai di Lembangan Sungai Setiu, Terengganu, Malaysia)

\author{
M.K. KOH, S. SURATMAN \& N. MOHD TAHIR*
}

\begin{abstract}
Dissolved and suspended particulate metals ( $\mathrm{Al}, \mathrm{Fe}, \mathrm{Cd}, \mathrm{Cu}, \mathrm{Zn}, \mathrm{Pb})$ in Setiu River basin, Terengganu which is situated at coastal area of southern South China Sea were investigated. The water samples were collected from nine stations from June 2007 to January 2008, in conjunction with the Southwest monsoon and Northeast monsoon. The average concentrations of dissolved $\mathrm{Al}, \mathrm{Fe}, \mathrm{Cd}, \mathrm{Cu}, \mathrm{Zn}$ and $\mathrm{Pb}$ were $\left(\mu \mathrm{g} \mathrm{L}^{-1}\right): 50 \pm 60,(2.0 \pm 3.4) \times 10^{2}, 2.5 \pm 2.6,3.0 \pm 1.4,7.5 \pm 5.1$ and 6.0 \pm 5.0 , respectively. Meanwhile, the concentrations of suspended particulate metals were $\left(\mu g g^{-1}\right):(13 \pm 10) \%$, $(10 \pm 13) \%, 15 \pm 13,65 \pm 94,(3.5 \pm 2.5) \times 10^{2}$ and $(1.2 \pm 1.5) \times 10^{2}$, respectively. Seasonal variations of dissolved and suspended particulate metals were observed. The results were compared with selected Malaysian national rivers, world average and established guidelines. In addition, the enrichment of suspended particulate metals and the partitioning of metals between dissolved and suspended particulate phases were discussed.
\end{abstract}

Keywords: Dissolved and suspended particulate metal; enrichment factor; metal partition coefficient; Setiu River (Malaysia)

\section{ABSTRAK}

Logam terlarut dan partikulat terampai ( $\mathrm{Al}, \mathrm{Fe}, \mathrm{Cd}, \mathrm{Cu}, \mathrm{Zn}, \mathrm{Pb})$ di lembangan Sungai Setiu, Terengganu yang terletak di perairan selatan Laut China Selatan telah dikaji. Sampel air telah diambil dari sembilan stesen dari Jun 2007 sehingga Januari 2008, bersesuaian dengan monsun Barat Daya dan Timur Laut. Kepekatan purata logam terlarut Al, Fe, Cd, $\mathrm{Cu}$, Zn dan Pb masing-masing ialah $\left(\mu \mathrm{g}^{-1}\right): 50 \pm 60,(2.0 \pm 3.4) \times 10^{2}, 2.5 \pm 2.6,3.0 \pm 1.4,7.5 \pm 5.1$ dan 6.0 \pm 5.0. Sementara itu, kepekatan logam partikulat terampai masing-masing ialah $\left(\mu g^{-1}\right):(13 \pm 10) \%,(10 \pm 13) \%, 15 \pm 13,65 \pm 94,(3.5 \pm 2.5)$ $\times 10^{2}$ dan $(1.2 \pm 1.5) \times 10^{2}$. Variasi bermusim untuk logam terlarut dan partikulat terampai telah diperhatikan. Hasil kajian telah dibandingkan dengan beberapa sungai yang terdapat di Malaysia, nilai purata kepekatan untuk dunia dan panduan piawai. Di samping itu, perkayaan untuk logam partikulat bersama-sama dengan pembahagian logam antara fasa terlarut dan partikulat terampai turut dibincangkan.

Kata kunci: Faktor perkayaan; logam terlarut dan partikulat terampai; pekali pembahagian logam; Sungai Setiu (Malaysia)

\section{INTRODUCTION}

Setiu River, with catchment area of approximately 188 $\mathrm{km}^{2}$ and $52 \mathrm{~km}$ in length, is located in Setiu district, east coast of Peninsular Malaysia. To date, Setiu is still a less developed district with low density of industrial activities. However, the 9-th Malaysia Plan has drafted the development of Setiu to become a portal of agricultural activities and ecotourism in the east coast of Malaysia (MDS 2009). Consequently, massive land clearing and construction activities to build infrastructure are being conducted at Setiu. The environmental stress is further exacerbated by the rapid population growth in Setiu district.

The Setiu River plays an essential role in the daily lives of local people as it supplies water for irrigation of agricultural land and support fresh water aquaculture. It also provides water for domestic usage, for which intake points are built along the riverbanks to extract raw water.
The Setiu River mouth is joined to a lagoon, well-known as Setiu Lagoon. Numerous studies have been conducted at Setiu Lagoon to monitor the water quality because of its economic contribution in supporting brackish water aquaculture and oyster farming (Suratman \& Talib 2015; Suratman et al. 2014). Presently, it is observed that sand mining activities are actively operated along the river. Nevertheless, there has been a lack of study on the Setiu River quality despite the fact that Setiu River is discharging into the lagoon. In view of the fact that the degradation of Setiu River quality could impact the lagoonal system, a study on Setiu River basin is of utmost importance for better management of Setiu Lagoon. Considering the high dependence of local people on Setiu River and the gaps in knowledge, there is an apparent need to study the Setiu River quality.

Metal contaminations could have greater effect than organic or microbial contamination because metal 
could be cycled over a long time through aqueous and particulate phases (Manjunantha et al. 2001). Being aware of the potential threat of metals to the local human and ecosystem, the present study aimed to determine the dissolved and suspended particulate metals (Al, Fe, Cd, $\mathrm{Cu}, \mathrm{Zn}, \mathrm{Pb}$ ) in Setiu River basin. The outcome of this study is likely to contribute to future research as the Setiu watershed is expected to become more complex and dynamic in terms of land use and population growth.

\section{METHODS}

Seven sampling trips to collect surface water samples at nine sampling stations, namely S1-S9 (Figure 1), were conducted between June 2007 and January 2008. The coordinate of the sampling stations are shown in Table 1. The study period coincided with Southwest monsoon (SWM) from June to September and Northeast monsoon (NEM) from late October to January.

The collected water samples were filtered through pre-weighed acetate cellulose membrane (with poresize $0.45 \mu \mathrm{m}$ ) immediately after sampling. The filtrate were acidified with concentrated nitric acid to $\mathrm{pH} 2$ and kept frozen until analysis. The membrane filters were oven-dried and weighed to obtain the actual weight of suspended particulate matter. For determination of dissolved metals, thawed filtrates were directly injected into the inductively coupled plasma-optical emission spectrometer (ICP-OES). Extraction is not required since the salinity of water samples was lower than $0.5 \mathrm{ppt}$ (Cenci \& Martin 2004; Sturgeon et al. 1981). Closed digestions of the membrane filters were performed using aqua regia (mixture of concentrated $\mathrm{HNO}_{3}$ and $\mathrm{HCl}$ at $1: 3$ ratio) in microwave oven at $180^{\circ} \mathrm{C}$ for $30 \mathrm{~min}$. The resulted acid extracts were then analyzed with ICP-OES and the concentrations of suspended particulate metals were normalized to their dry solid weight. The analysis of dissolved and suspended particulate metals generally conforms to APHA-AWWA-WEF (2005) standard.

Other physical parameters such as $\mathrm{pH}$, dissolved oxygen saturation (DO), temperature and salinity were measured in-situ using pre-calibrated YSI MultiParameter Water Quality Sonde. Monthly total rainfall of Setiu during the study period was obtained from Malaysia Meteorological Department (MMD). Essential quality control measures such as reagent blank analysis, standard addition and continuing calibration verification (CCV) were strictly practiced. All the blank controls gave insignificant levels of concentrations compared to samples.
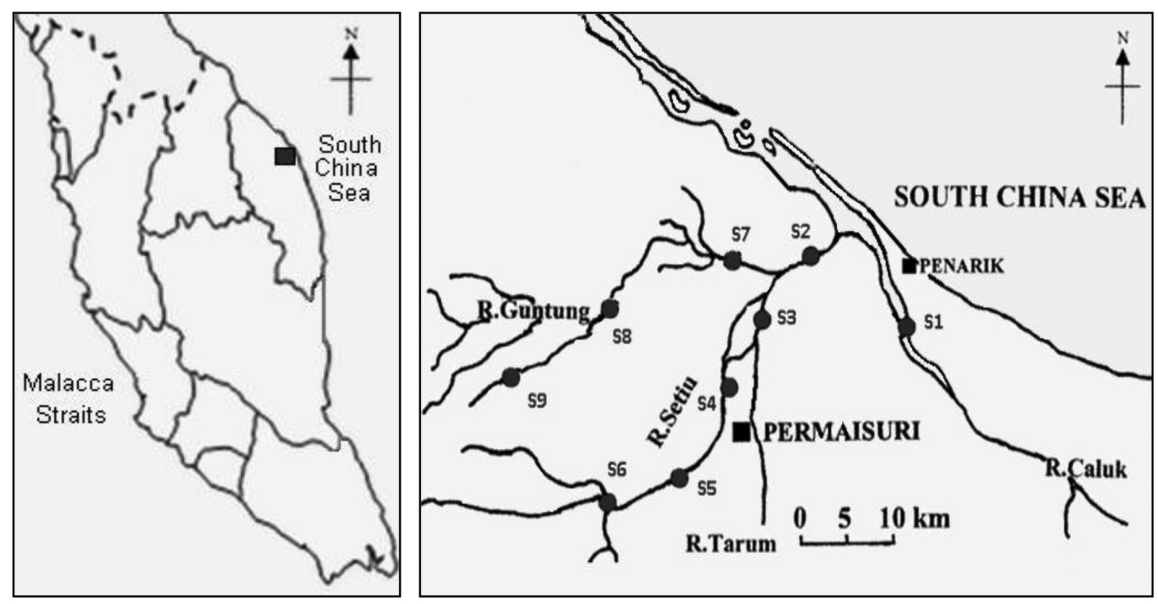

FIGURE 1. Location of Setiu district and sampling stations (S1-S9) distributed in Setiu River basin

TABLE 1. Coordinates of sampling stations (S1-S9)

\begin{tabular}{|c|c|c|}
\hline \multirow{2}{*}{$\begin{array}{l}\text { Sampling } \\
\text { stations }\end{array}$} & \multicolumn{2}{|c|}{ Coordinates } \\
\hline & Latitude & Longitude \\
\hline S1 & $5^{\circ} 35^{\prime} 40.80 ” \mathrm{~N}$ & $102^{\circ} 49^{\prime} 9.84 ” \mathrm{E}$ \\
\hline $\mathrm{S} 2$ & $5^{\circ} 35^{\prime} 23.60 " \mathrm{~N}$ & $102^{\circ} 46^{\prime} 57.299^{\prime \prime} \mathrm{E}$ \\
\hline S3 & $5^{\circ} 32^{\prime} 48.733^{\prime \prime} \mathrm{N}$ & $102^{\circ} 45^{\prime} 26.92^{\prime \prime} \mathrm{E}$ \\
\hline S4 & $5^{\circ} 31^{\prime} 46.82^{\prime \prime} \mathrm{N}$ & $102^{\circ} 44^{\prime} 47.37^{\prime \prime} \mathrm{E}$ \\
\hline S5 & $5^{\circ} 29^{\prime} 48.60 " \mathrm{~N}$ & $102^{\circ} 43^{\prime} 23.22^{\prime \prime} \mathrm{E}$ \\
\hline S6 & $5^{\circ} 28^{\prime} 57.94 ” \mathrm{~N}$ & $102^{\circ} 41^{\prime} 9.90^{\prime \prime} \mathrm{E}$ \\
\hline S7 & $5^{\circ} 36^{\prime} 37.16^{\prime \prime} \mathrm{N}$ & $102^{\circ} 44^{\prime} 5.46^{\prime \prime} \mathrm{E}$ \\
\hline S8 & $5^{\circ} 34^{\prime} 43.50 ” \mathrm{~N}$ & $102^{\circ} 42^{\prime} 3.09 ” \mathrm{E}$ \\
\hline S9 & $5^{\circ} 33^{\prime} 22.07^{\prime \prime} \mathrm{N}$ & $102^{\circ} 40^{\prime} 30.95^{\prime \prime} \mathrm{E}$ \\
\hline
\end{tabular}




\section{RESULTS AND DISCUSSION}

The percentage of recovery for standard addition and CCV were generally within the acceptable range (Table 2). Therefore, the employed analytical methods are suitable for metal determination.

TABLE 2. Percentage of recovery achieved in standard addition and $\mathrm{CCV}$

\begin{tabular}{ccc}
\hline \multirow{2}{*}{ Elements } & \multicolumn{2}{c}{ Percentage of recovery $(\%)$} \\
\cline { 2 - 3 } & Standard addition $(n=8)$ & $\mathrm{CCV}(n=15)$ \\
\hline $\mathrm{Al}$ & $89 \pm 6.0$ & $98 \pm 9.0$ \\
$\mathrm{Fe}$ & $71 \pm 14$ & $85 \pm 7.0$ \\
$\mathrm{Cd}$ & $97 \pm 0.10$ & $94 \pm 8.0$ \\
$\mathrm{Cu}$ & $98 \pm 0.40$ & $96 \pm 8.0$ \\
$\mathrm{Zn}$ & $96 \pm 2.0$ & $95 \pm 7.5$ \\
$\mathrm{~Pb}$ & $98 \pm 0.80$ & $100 \pm 9.5$ \\
\hline
\end{tabular}

(note: mean \pm standard deviation)
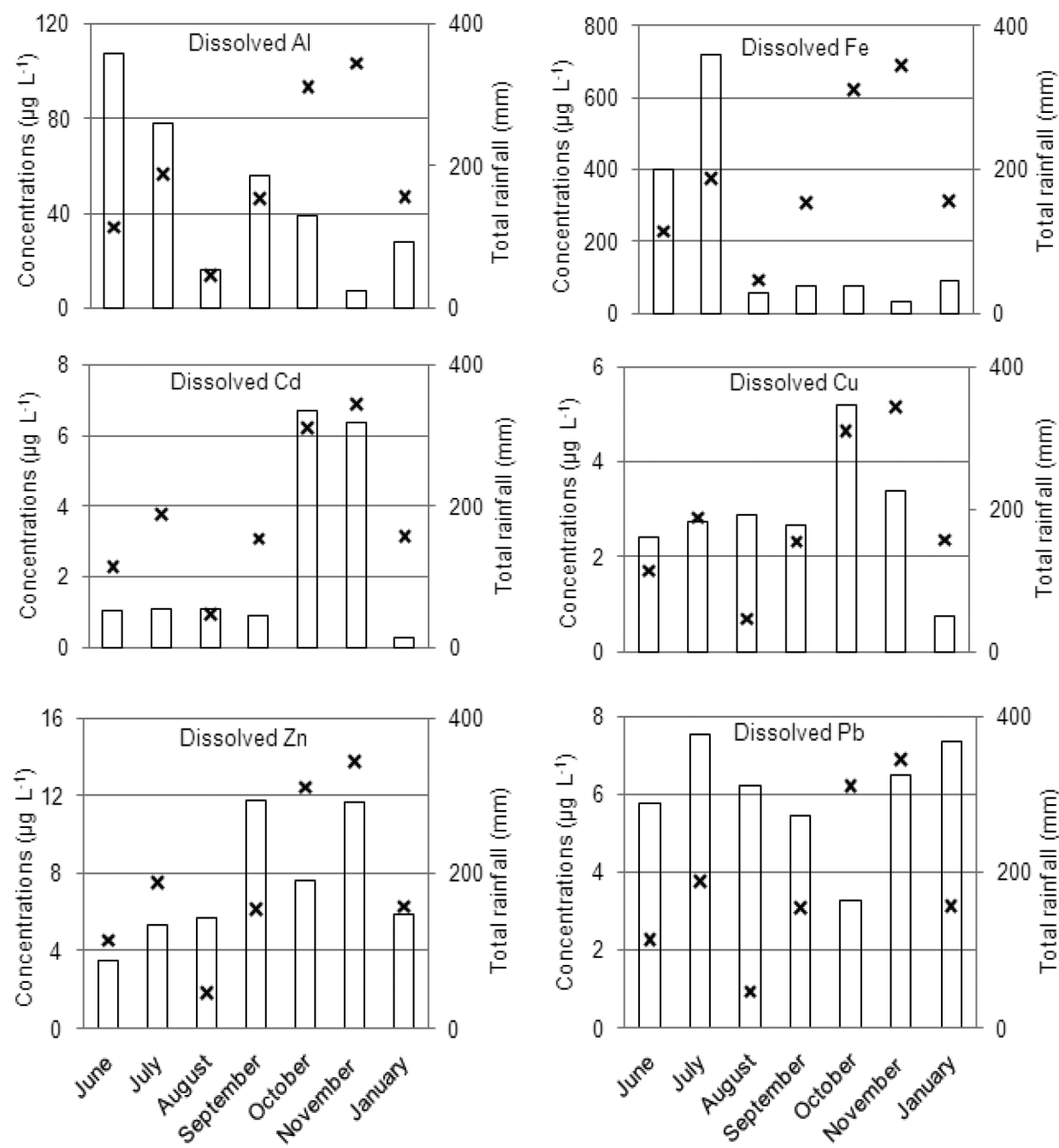

Metal concentrations x Total rainfall
In-situ parameters such as $\mathrm{pH}, \mathrm{DO}$, temperature and salinity did not show significant variations between sampling trips and stations. The Setiu River is slightly acidic with average $\mathrm{pH}$ ranged from 5.80 to 6.30 . Average Do levels were between 5.93 and $8.94 \mathrm{mg} \mathrm{L}^{-1}$. The river water temperature was within 27.0 and $29.0^{\circ} \mathrm{C}$. All the sampling stations are fresh-water dominated with salinity ranged between 0.01 and 0.03 ppt.

\section{DISSOLVED METALS}

Dissolved metals were measured in 63 samples and the results varied in a wide range between elements (Figure 2). Dissolved $\mathrm{Al}$ and $\mathrm{Fe}$ had much higher concentrations compared with other elements since they are Earth's major elements. Strong correlation was found between dissolved $\mathrm{Al}$ and $\mathrm{Fe}(r=0.75, p \leq 0.05)$, suggesting that they could have similar origin. Seasonal variations were observed in the temporal distributions of dissolved $\mathrm{Al}$ 
and $\mathrm{Fe}$, in which higher concentrations usually occurred during SWM compared to NEM. Therefore, the increases of rainfall during NEM appeared to have dilution effect on dissolved $\mathrm{Al}$ and $\mathrm{Fe}$.

On the contrary, high rainfall during NEM increased the concentrations of dissolved $\mathrm{Cd}, \mathrm{Cu}$ and $\mathrm{Zn}$. Strong to moderate positive correlations were found between rainfall and dissolved $\mathrm{Cd}(r=0.88, p \leq 0.01), \mathrm{Cu}(r=0.60, p \leq 0.20)$ as well as $\mathrm{Zn}(r=0.60, p \leq 0.20)$, indicating that land surface runoff may contain considerable amount of these elements. The $p$-value of more than 0.05 could be ascribed to the insufficiency number of samples. Dissolved $\mathrm{Cd}$ was also strongly correlated with $\mathrm{Cu}(r=0.80, p \leq 0.05)$. Unlike other elements, dissolved $\mathrm{Pb}$ had neither noticeable seasonal variations nor significant correlations with other dissolved elements.

Compared with selected Malaysian national rivers located within urbanized area such as Langat River, Juru River and Serin River, dissolved metal concentrations in Setiu River are generally lower (Table 3). Nevertheless, the concentrations of dissolved $\mathrm{Cd}, \mathrm{Cu}$ and $\mathrm{Pb}$ were several folds higher than unpublished data acquired earlier by Noor Fazilah (2002), suggesting the increase of anthropogenic influences on Setiu watershed. In fact, the current results are higher than the world average for pristine river. To evaluate the Setiu River quality, concentrations of dissolved metals were assessed with drinking water guidelines proposed by World Health Organization (WHO) and United States Environmental Protection Agency (USEPA) (Table 3). The assessment indicates that Setiu River is still complying with WHO and USEPA guidelines.

\section{SUSPENDED PARTICULATE METALS}

The results infer that metals are predominantly in suspended particulate form compared with dissolved concentrations (Figure 3). Concentrations of suspended particulate $\mathrm{Al}$ and $\mathrm{Fe}$ were higher than other elements by 3-4 orders of magnitude. The suspended particulate metals exhibited clear seasonal variability, where higher and/or maximum concentrations generally occurred during NEM. This seasonal variation is more obvious in the temporal distributions of suspended particulate $\mathrm{Fe}, \mathrm{Cd}$, $\mathrm{Zn}$ and $\mathrm{Pb}$. Increased of rainfall during NEM could have enhanced the input of metal-rich particulate materials into Setiu River. Strong inter-correlations were found between all the suspended particulate metals $(0.70 \leq r \leq$ $0.99,0.001 \leq p \leq 0.09$ ), suggesting high probability of their common origin.

The concentrations of suspended particulate $\mathrm{Al}, \mathrm{Fe}$, $\mathrm{Cd}$ and $\mathrm{Pb}$ in Setiu River were higher than the world average while $\mathrm{Cu}$ and $\mathrm{Zn}$ are lower (Table 4). The results were also compared to Artois-Picardie Basin (APB) and SEQ-Eau scales for river suspended particulate metals classification (Table 4).

It should be noted that APB and SEQ-Eau scales were established for assessing the river suspended particulate metals pollution in France. Considering the climatic and geological differences between France and Malaysia, APB and SEQ-Eau scales may not classify the Setiu River quality accurately. However, the information from APB and SEQ-Eau scales are still adequate for reference while a Malaysian or international scale is yet to be established. In addition, theoretical values proposed in SEQ-Eau have not taken into account the natural background levels and hence it may overestimate the degree of pollution (Meybeck et al. 2007). With reference to APB scale, suspended particulate metals in Setiu River were still below the $L_{2}$ class, suggesting the absence of established contamination. Meanwhile, a more stringent assessment scale, SEQ-Eau, indicates that suspended particulate $\mathrm{Cd}$ and $\mathrm{Pb}$ were in the $r$-code, signifying the potential of extreme impact on ecology or human health.

To facilitate the estimation of metal enrichment in suspended particulate matter, Al-normalized enrichment factor (EF) was being calculated. The EF was expressed as the following equation (Gordeev et al. 2004):

TABLE 3. Concentrations of dissolved metals in Setiu River, selected Malaysian national rivers and world average for pristine river. Drinking water guidelines proposed by WHO and USEPA

\begin{tabular}{|c|c|c|c|c|c|c|}
\hline \multirow{2}{*}{ Rivers } & \multicolumn{6}{|c|}{ Average concentrations of dissolved metals $\left(\mu \mathrm{g} \mathrm{L}^{-1}\right)$} \\
\hline & $\mathrm{Al}$ & $\mathrm{Fe}$ & $\mathrm{Cd}$ & $\mathrm{Cu}$ & $\mathrm{Zn}$ & $\mathrm{Pb}$ \\
\hline Setiu $^{1}$ & $50 \pm 60$ & $(2.0 \pm 3.4) \times 10^{2}$ & $2.5 \pm 2.6$ & $3.0 \pm 1.4$ & $7.5 \pm 5.1$ & $6.0 \pm 5.0$ \\
\hline Setiu $^{2}$ & nd & nd & 0.50 & 0.40 & nd & 0.50 \\
\hline Nerus $^{3}$ & nd & nd & $(6.0 \pm 2.0) \times 10^{-2}$ & $1.4 \pm 0.60$ & $5.2 \pm 4.9$ & $0.90 \pm 0.40$ \\
\hline Langat $^{4}$ & nd & $(1.3 \pm 2.3) \times 10^{3}$ & $50 \pm 100$ & $(1.5 \pm 4.0) \times 10^{2}$ & $25 \pm 80$ & $70 \pm 100$ \\
\hline Juru $^{5}$ & nd & nd & $(1.7 \pm 0.50) \times 10^{2}$ & $50 \pm 40$ & $90 \pm 20$ & $(3.0 \pm 0.80) \times 10^{2}$ \\
\hline Serin $^{6}$ & nd & nd & $5.0 \pm 4.0$ & $40 \pm 50$ & $96 \pm 70$ & $50 \pm 70$ \\
\hline $\begin{array}{l}\text { World average } \\
\text { (pristine river) }^{7}\end{array}$ & 40 & 50 & $1.0 \times 10^{-3}$ & 1.4 & 0.20 & $4.0 \times 10^{-2}$ \\
\hline $\mathrm{WHO}^{8}$ & $2.0 \times 10^{2}$ & $3.0 \times 10^{3}$ & 3.0 & $2.0 \times 10+3$ & $3.0 \times 10+3$ & 10 \\
\hline USEPA $^{9}$ & $2.0 \times 10^{3}$ & $3.0 \times 10^{2}$ & 5.0 & $1.3 \times 10+3$ & $5.0 \times 10+3$ & 15 \\
\hline
\end{tabular}

"nd; not determine

(1) This study; (2) Noor Fazilah (2002); (3) Poh et al. (2004); (4) Yusof et al. (2009); (5) Abbas et al. (2008); (6) Ling et al. (2010); (7) Meybeck et al. (1996); (8) WHO (2008); (9) USEPA (2009) 

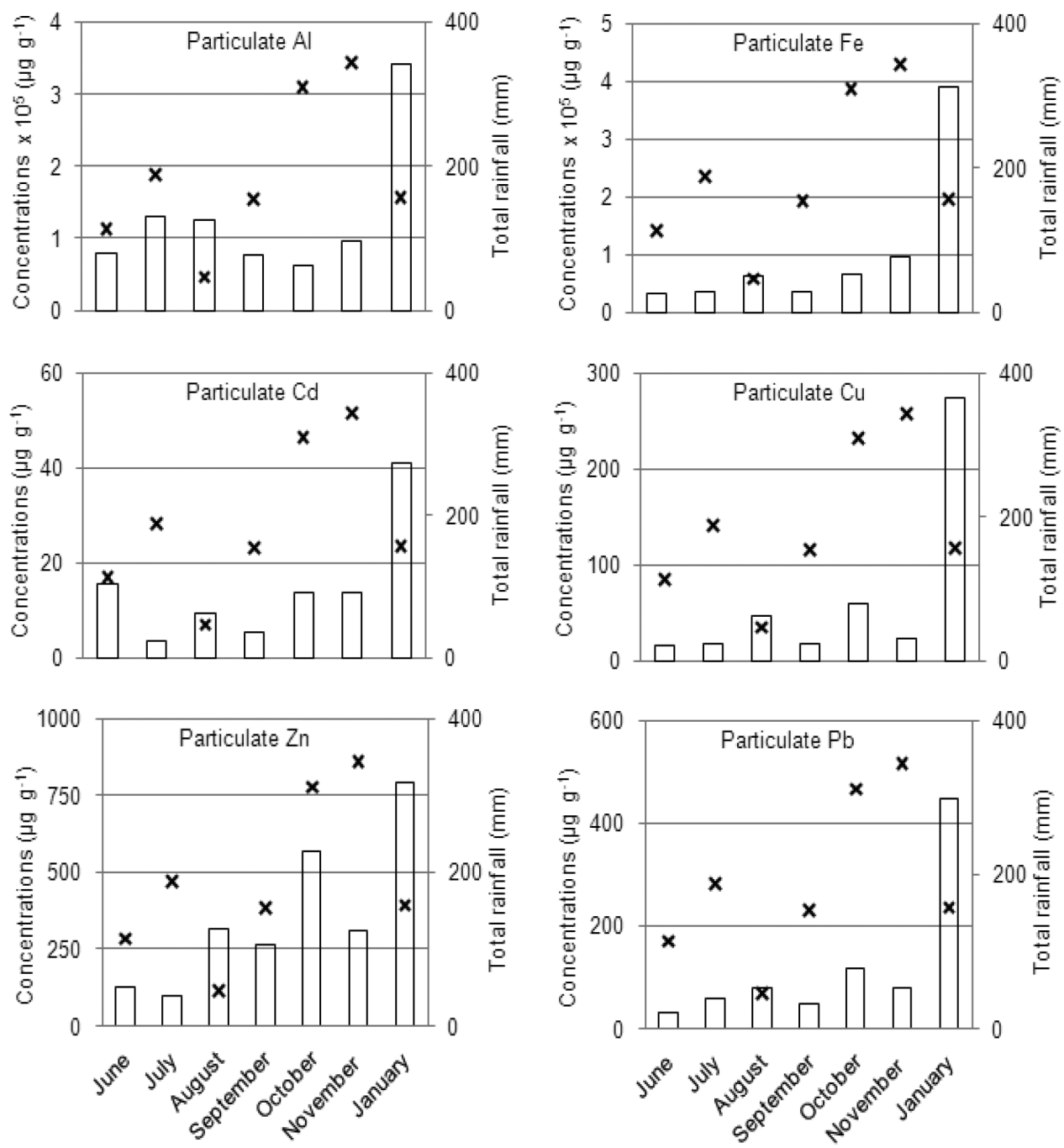

FIGURE 3. Spatially averaged concentrations of suspended particulate metals and monthly total rainfall

TABLE 4. Concentrations of suspended particulate metals in Setiu River and world average.

Artois-Picardie Basin (APB) and SEQ-Eau scales for river suspended particulate metals classification

\begin{tabular}{|c|c|c|c|c|c|c|c|}
\hline \multirow{2}{*}{ Rivers } & & \multicolumn{6}{|c|}{ Average concentrations of suspended particulate metals $\left(\mu \mathrm{g} \mathrm{g}^{-1}\right)$} \\
\hline & & $\mathrm{Al}(\%)$ & $\mathrm{Fe}(\%)$ & $\mathrm{Cd}$ & $\mathrm{Cu}$ & $\mathrm{Zn}$ & $\mathrm{Pb}$ \\
\hline Setiu $^{1}$ & & $13 \pm 10$ & $10 \pm 13$ & $15 \pm 13$ & $65 \pm 94$ & $(3.5 \pm 2.5) \times 10^{2}$ & $(1.2 \pm 1.5) \times 10^{2}$ \\
\hline World average $^{2}$ & & $8.7 \pm 6.0$ & $5.8 \pm 4.8$ & $1.6 \pm 4.2$ & $76 \pm 135$ & $(2.1 \pm 2.4) \times 10^{2}$ & $61 \pm 91$ \\
\hline \multirow[t]{2}{*}{$\mathrm{APB}^{3,4}$} & $L_{1}$ & nd & nd & 6 & 90 & $2.4 \times 10^{2}$ & $6.0 \times 10^{2}$ \\
\hline & $L_{2}$ & nd & nd & 18 & $2.7 \times 10^{2}$ & $1.8 \times 10^{3}$ & $7.2 \times 10^{2}$ \\
\hline \multirow[t]{2}{*}{ SEQ-Eau ${ }^{3,4}$} & $g$ & nd & nd & $9.0 \times 10^{-2}$ & 27 & 14 & 10 \\
\hline & $r$ & nd & nd & 5 & $1.1 \times 10^{2}$ & $1.2 \times 10^{3}$ & 50 \\
\hline
\end{tabular}

$L_{l}$ : probable contamination level, $L_{2}$ : established contamination, $g$ : green with some contamination without ecological or human health impact, $r$ : red with extreme impact (1)This study; (2) Viers et al. (2009); (3) Meybeck et al. (2007); (4) Lourino-Cabana et al. (2010)

$$
\mathrm{EF}(X)=\left[X / \mathrm{Al}_{(\text {sample })}\right] /\left[X / \mathrm{Al}{ }_{(\text {world average })}\right] .
$$

The average metal concentrations in world rivers suspended particulate matter are adapted from Viers et al. (2009). EF of $>1$ indicates enrichment; $<1$ indicates depletion; =1 indicates no changes in the relative abundance of element. Compared with world average, $\mathrm{Fe}$ (1.20), Cd (6.30) and Zn (3.90) are enriched in Setiu River suspended particulate matter while $\mathrm{Cu}(0.57)$ and $\mathrm{Pb}(0.40)$ are in depletion. The parenthesis indicates EF of respective metals. Notable $\mathrm{Cd}$ and $\mathrm{Zn}$ enrichment could be attributed to localized input from domestic sewage and 
agro-based industries. Untreated domestic sewage could be discharged into Setiu River through point and/or nonpoint sources since there is a lack of sewage treatment facilities within the watershed. Fertilizer and herbicide application to arable land could also lead to $\mathrm{Cd}$ and $\mathrm{Zn}$ enrichment as these elements often exist as impurities (Gimeno-Garcia et al. 1996; Luo et al. 2007; Zhang \& Shan 2008). Despite the anthropogenic source, contribution of local lithology (natural source) to $\mathrm{Cd}$ and $\mathrm{Zn}$ enrichment could not be ruled out. However, we are uncertain of the relative importance of anthropogenic versus natural sources of suspended particulate $\mathrm{Cd}$ and $\mathrm{Zn}$ due to the lack of published geochemical data for Setiu area.

\section{METAL PARTITION COEFFICIENT}

The metal partition coefficient $\left(K_{p}\right)$ describes the ratio of suspended particulate metal concentration (normalized to dry solid weight) to dissolved metal concentration. $K_{p}$ is expressed as the following equation (Allison et al. 2005):

$$
K_{p}=\frac{\text { Concentration of suspended particulate metal }\left(\mu \mathrm{g} \mathrm{g}^{-1}\right)}{\text { Concentration of dissolved metal }\left(\mu \mathrm{g} \mathrm{L} \mathrm{L}^{-1}\right)} .
$$

Linear isothermal expression of $K_{p}$ assumes local or instant equilibrium of particulate and dissolved metals
(Gallo et al. 2006). $K_{p}$ computation is useful for quantifying the relative sorption strength of individual metal to particulate matter. The sorption strength of metals to particulate matter will determine their fate and transport in the aquatic environment (Benoit \& Rozan 1999; Gueguen et al. 2011). In general, metals complexes with particulate matter are considered to be less bioavailable than ionic or dissolved metals. Average $(n=63) K_{p}$ for $\mathrm{Al}, \mathrm{Fe}, \mathrm{Cd}, \mathrm{Cu}, \mathrm{Zn}$ and $\mathrm{Pb}$ are $\left(\mathrm{L}^{-1} \mathrm{~g}\right):(6.80 \pm 9.40) \times 10^{3}$, $(1.40 \pm 2.00) \times 10^{3}, 25.0 \pm 85.0,23.0 \pm 55.0,70.0 \pm 150.0$ and $80.0 \pm 230.0$, respectively. Therefore, relative sorption strength of measured elements are in decreasing trend of $\mathrm{Al}>\mathrm{Fe}>\mathrm{Pb}>\mathrm{Zn}>\mathrm{Cd}>\mathrm{Cu}$. The $K_{p}$ for $\mathrm{Al}$ and $\mathrm{Fe}$ are higher than $\mathrm{Pb}, \mathrm{Zn}, \mathrm{Cd}$ and $\mathrm{Cu}$ by two orders of magnitude. This result infers that major elements $(\mathrm{Al}$ and $\mathrm{Fe}$ ) have higher particle sorption affinity compared with trace elements $(\mathrm{Pb}, \mathrm{Zn}, \mathrm{Cd}$ and $\mathrm{Cu})$. In nature, $\mathrm{Al}$ and $\mathrm{Fe}$ are considered as dominant sorbents because they are common in rivers and soils, where they tend to coat other particles (Gaillardet et al. 2005). Therefore, it could be deduce that a major fraction of $\mathrm{Al}$ and $\mathrm{Fe}$ are transported with solid phase. Meanwhile, trace metals $(\mathrm{Pb}, \mathrm{Zn}, \mathrm{Cd}$ and $\mathrm{Cu}$ ) exist in relatively labile ionic form or dissolved form (Hamad et al. 2012). The observation on the distinctness of $K_{p}$ for major elements and trace elements was also reported by Benoit and Rozan (1999). The large standard deviation indicates
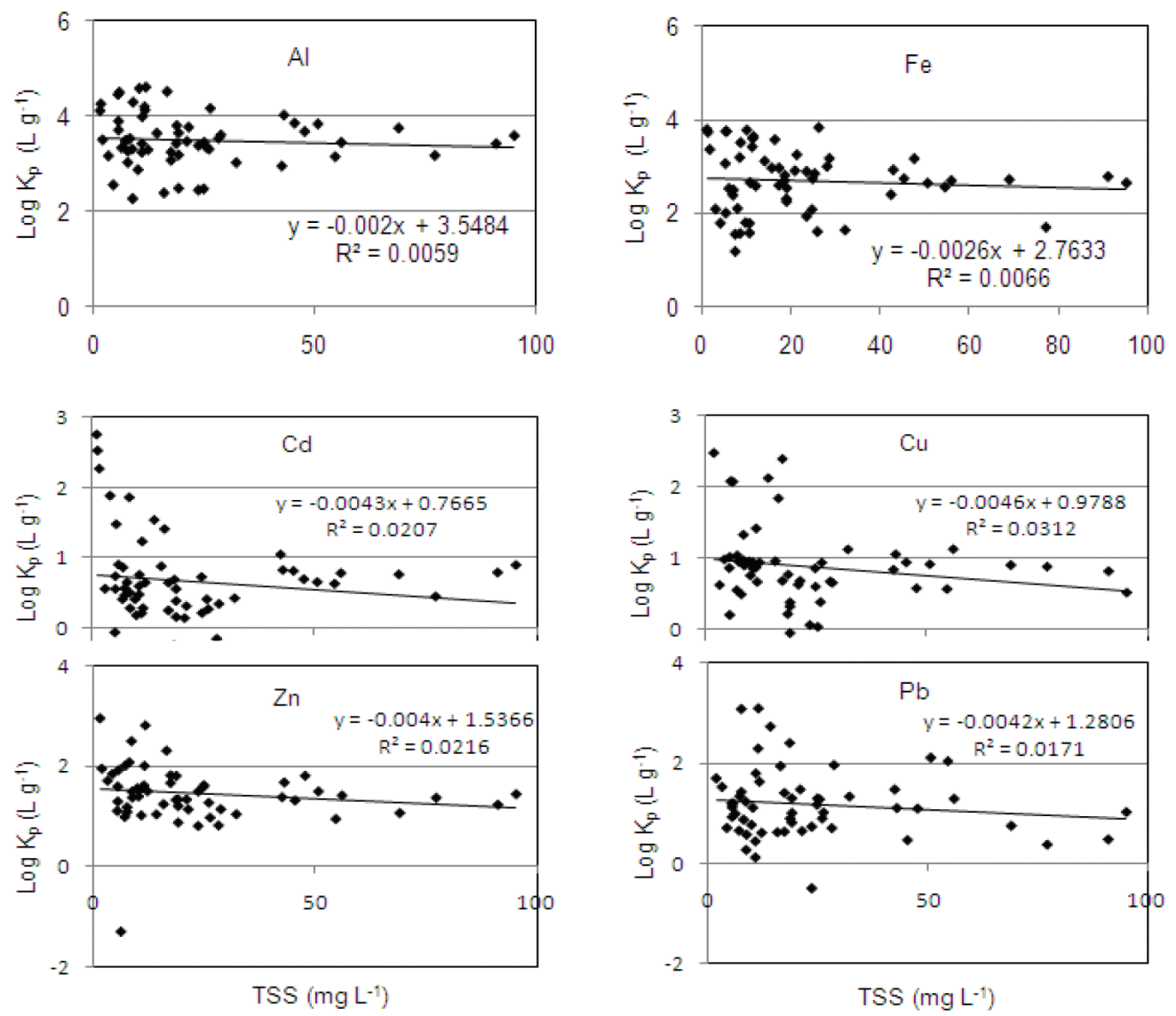

FIGURE 4. Variations diagram of Log $K_{p}$ versus TSS concentrations for studied elements 
that $K_{p}$ has scatter distribution and hence the partition of metals in suspended particulate and dissolved form is considerably unstable. Forcing factors such as rainfall event, pollutant plume emission and river hydrodynamic could have resulted in the $K_{p}$ variations (Gueguen \& Dominik 2003; Owen et al. 1996).

Variations diagram of $\log K_{p}$ for each elements were plotted using total suspended solid (TSS) concentrations as $x$-axis (Figure 4 ). The $K_{p}$ of all elements appears to have inverse correlation with TSS. This inverse correlation is frequently discussed in related literatures and is commonly termed as 'particle concentration effect' (Balls 1989; Jiann et al. 2005; Koshikawa et al. 2007). The inverse relationship usually occurs when substantial amount of free-metals bound to colloids which may not be retained in filtering processes due to their small particle size (1.20 $\mu \mathrm{m}-1 \mathrm{kDa})$ (Gallo et al. 2006; Moran et al. 1996). The low salinity in our study area could have enhanced the suspension of metal bound colloids in water column. In high salinity condition, colloids are susceptible to coagulation and thereby forming larger settling particles (Gueguen \& Dominik 2003).

\section{CONCLUSION}

Based on the study of dissolved and suspended particulate metals in Setiu River, the following conclusions can be drawn:

Average concentrations of dissolved $\mathrm{Al}, \mathrm{Fe}, \mathrm{Cd}, \mathrm{Cu}$, $\mathrm{Zn}$ and $\mathrm{Pb}$ are $\left(\mu \mathrm{g} \mathrm{L}^{-1}\right): 50 \pm 60,(2.0 \pm 3.4) \times 10^{2}, 2.5 \pm 2.6$, $3.0 \pm 1.4,7.5 \pm 5.1$ and $6.0 \pm 5.0$, respectively. Higher rainfall during NEM appeared to have dilution effect on dissolved $\mathrm{Al}$ and $\mathrm{Fe}$ while $\mathrm{Cd}, \mathrm{Cu}$ and $\mathrm{Zn}$ were enriched. The concentrations of dissolved $\mathrm{Cd}, \mathrm{Cu}$ and $\mathrm{Pb}$ were several folds higher than unpublished data acquired in year 2002. However, the Setiu River quality is still complying with WHO and USEPA guidelines.

Average concentrations of suspended particulate Al, $\mathrm{Fe}, \mathrm{Cd}, \mathrm{Cu}, \mathrm{Zn}$ and $\mathrm{Pb}$ are $\left(\mu \mathrm{g} \mathrm{g}^{-1}\right):(13 \pm 10) \%,(10 \pm 13) \%$, $15 \pm 13,65 \pm 94,(3.5 \pm 2.5) \times 10^{2}$ and $(1.2 \pm 1.5) \times 10^{2}$, respectively. Higher and/or maximum concentrations of suspended particulate metals generally occurred during NEM. The suspended particulate $\mathrm{Al}, \mathrm{Fe}, \mathrm{Cd}$ and $\mathrm{Pb}$ in Setiu River are higher than the world average concentrations while $\mathrm{Cu}$ and $\mathrm{Zn}$ are lower.

Relative sorption strength of metals to particulate matter are in the decreasing trend of $\mathrm{Al}>\mathrm{Fe}>\mathrm{Pb}>\mathrm{Zn}>\mathrm{Cd}>\mathrm{Cu}$. The $K_{p}$ of all elements shows inverse correlation with TSS, owing to the 'particulate concentration effect'.

\section{ACKNOWLEDGEMENTS}

We are grateful to the Department of Chemical Sciences, Faculty of Science and Technology, Universiti Malaysia Terengganu for partially funding the research. The manuscript benefited from the comments of anonymous reviewer.

\section{REFERENCES}

Abbas, F., Alkarkhi, M., Anees, A., Norli, I. \& Mat Easa, A. 2008. Multivariate analysis of heavy metals concentrations in river estuary. Environmental Monitoring and Assessment 143:179-186.

Allison, J.D. \& Allison, T.L. 2005. Partition Coefficient for Metals in Surface Water, Soil and Waste. U.S. Environmental Protection Agency, Athens. Publication No. EPA/600/R-05/074.

American Public Health Agency, American Water Works Association and Water Environment Federation (APHAAWWA-WEF). 2005. Standard Methods for Examination of Water and Wastewater (21st ed.). Washington: APHAAWWA-WEF.

Balls, P.W. 1989. The partition of trace metals between dissolved and particulate phases in European coastal waters: A compilation of field data and comparison with laboratory studies. Netherland Journal of Sea Research 23: 7-14.

Benoit, G. \& Rozan, T.F. 1999. The influence of size distribution on the particle concentration effect and trace metal partitioning in rivers. Geochimica et Cosmochimica Acta 63(1): 113-127.

Cenci, R.M. \& Martin, J.M. 2004. Concentration and fate of trace metals in Mekong River Delta. Science of the Total Environment 332: 167-182.

Gallo, M., Trento, A., Alvarez, A., Beldomenico, H. \& Campagnoli, D. 2006. Dissolved and particulate heavy metals in the Salado River (Santa Fe, Argentina). Water, Air, and Soil Pollution 174: 368-384.

Gaillardet, J., Viers, J. \& Dupre, B. 2005. Trace elements in river waters. In Surface and Groundwater, Weathering, and Soils, edited by Drever, J.I. UK: Elsevier Limited. p. 260.

Gimeno-Garcia, E., Andreu, V. \& Boluda, R. 1996. Heavy metals incidence in the application of inorganic fertilizers and pesticides to rice farming soils. Environmental Pollution 92: $19-25$.

Gordeev, V.V., Rachold, V. \& Vlasova, I.E. 2004. Geochemical behaviour of major and trace elements in suspended particulate material of the Irtysh river, the main tributary of the Ob river, Siberia. Applied Geochemistry 19: 593-610.

Gueguen, C. \& Dominik, J. 2003. Partitioning of trace metals between particulate, colloidal and truly dissolved fractions in a polluted river: The Upper Vistula River (Poland). Applied Geochemistry 18: 457-470.

Gueguen, C., Clarisse, O., Perroud, A. \& McDonald, A. 2011. Chemical speciation and partitioning of trace metals $(\mathrm{Cd}, \mathrm{Co}$, $\mathrm{Cu}, \mathrm{Ni}, \mathrm{Pb})$ in the lower Athabasca river and its tributaries (Alberta, Canada). Journal of Environmental Monitoring 13: $2865-2872$.

Hamad, S.H., Schauer, J.J., Shafer, M.M., Al-Raheem, E.A. \& Satar, H. 2012. The distribution between the dissolved and the particulate forms of 49 metals across the Tigris River, Baghdad, Iraq. The Scientific World Journal Article ID 246059.

Jiann, K., Wen, L. \& Santschi, P.H. 2005. Trace metals (Cd, Cu, $\mathrm{Ni}$ and $\mathrm{Pb}$ ) partitioning, affinities and removal in the Danshuei River estuary, a micro-tidal, temporally anoxic estuary in Taiwan. Marine Chemistry 96: 293-313.

Koshikawa, M.K., Takamatsu, T., Takada, J., Zhu, M., Xu, B., Chen, Z., Murakami, S., Xu, K. \& Watanabe, M. 2007. Distributions of dissolved and particulate elements in the Yangtze estuary in 1997-2002: Background data before the 
closure of the Three Gorges Dam. Estuarine, Coastal and Shelf Science 71: 26-36.

Ling, T., Srikaran, R., Kho, C. \& Lee, N. 2010. Organic matter, nutrients and trace metals of Serin River. World Applied Sciences Journal 8: 496-502.

Lourino-Cabana, B., Lesven, L., Billon, G., Proix, N., Recourt, P., Ouddane, B., Fischer, J.C. \& Boughriet, A. 2010. Impacts of metal contaminations in calcareous waters of Deule rinoRiver (France): Water quality and thermodynamic studies on metallic mobility. Water, Air and Soil Pollution 206: 187-201.

Luo, W., Lu, Y., Giesy, J.P., Wang, T., Shi, Y., Wang, G. \& Xing, Y. 2007. Effects of land use on concentrations of metals in surface soils and ecological risk around Guanting Reservoir, China. Environmental Geochemistry and Health 29: 459-471.

Majlis Daerah Setiu (MDS). 2009. Rancangan tempatan Daerah Setiu (RTDS). http://mds.terengganu.gov.my/ rancangantempatan. Accessed on 17 February 2009.

Manjunatha, B.R., Balakrishna, K., Shankar, R. \& Mahalingam, T.R. 2001. Geochemistry and assessment of metal pollution in soils and river components of monsoon-dominated environment near Khawar, southwest coast of India. Environmental Geology 40: 1462-1470.

Meybeck, M., Friedrich, G., Thomas, R. \& Chapman, D. 1996. Rivers. In Water Quality Assessments-A Guide to Use Biota, Sediments and Water in Environmental Monitoring, edited by Chapman, D. Cambridge: University Press.

Meybeck, M., Lestel, L., Bonte, P., Moilleron, R., Colin, J.L., Rousselot, O., Herve, D., Ponteves, C., Grosbois, C. \& Thevenot, D.R. 2007. Historical perspective of heavy metals contamination $(\mathrm{Cd}, \mathrm{Cr}, \mathrm{Cu}, \mathrm{Hg}, \mathrm{Pb}, \mathrm{Zn})$ in the Seine River basin (France) following a DPSIR approach (1950-2005). Science of the Total Environment 375: 204-231.

Moran, S.B., Yeats, P.A. \& Balls, P.W. 1996. On the role of colloids on trace metal solid-solution partitioning in continental shelf waters: A comparison of model results and field data. Continental Shelf Research 16(3): 397-408.

Noor Fazilah, A.M. 2002. Determination of selected dissolved metals in Setiu River basin, Terengganu, B.Sc Thesis, Universiti Malaysia Terengganu, Malaysia (unpublished).

Owen, R.E., Balls, P.W. \& Price, N.B. 1996. Physicochemical processes and their effects on the composition of suspended particulate materials in estuaries: Implications for monitoring and modeling. Marine Pollution Bulletin 34: 51-60.

Poh, S.C., Suratman, S., Chew, C.K., Azhar, M.S.\& Mohd Tahir, N. 2004. Metal geochemistry of Nerus River, Terengganu. The Malaysian Journal of Analytical Sciences 12: 593-599.

Sturgeon, R.E., Berman, S.S., Willie, S.N. \& Desaulniers, J.A.H. 1981. Preconcentration of trace elements from seawater with silica-immobilized 8-hydroxyquinoline. Analytical Chemistry 53: 2340-2377.
Suratman, S., Hussein, A.N.A.R., Latif, M.T. \& Weston, K. 2014 Reassessment of physico-chemical water quality in Setiu Wetland, Malaysia. Sains Malaysiana 43(8): 1127-1131.

Suratman, S. \& Talib, M.T. 2015. Reassessment of nutrient status in Setiu Wetland, Terengganu, Malaysia. Asian Journal of Chemistry 27(1): 239-242.

United States Environmental Protection Agency (USEPA). 2009. Inorganic chemicals in drinking water contaminants. http:// www.epa.gov/safewater/contaminants/index.html\#inorganic. Accessed on 6 October 2009

Viers, J., Dupre, B . \& Gaillardet, J. 2009. Chemical composition of suspended sediments in World Rivers: New insights from new database. Science of the Total Environment 407: 853-868.

Yusof, N., Haraguchi, A., Hassan, M.A., Othman, M.R., Wakisaka, M. \& Shirai, Y. 2009. Measuring organic carbon, nutrients and heavy metals in rivers receiving leachate from controlled and uncontrolled municipal solid waste (MSW) landfills. Waste Management 29: 2666-2680.

World Health Organization (WHO). 2008. Chemical Fact Sheets in Guidelines for Drinking-Water Quality. 3rd ed. Geneva: WHO Press.

Zhang, H. \& Shan, B. 2008. Historical records of heavy metal accumulation in sediments and the relationship with agricultural intensification in the Yangtze-Huaihe region, China. Science of the Total Environment 399: 113-120.

M.K. Koh, S. Suratman \& N. Mohd Tahir* Institute of Oceanography \& Environment Universiti Malaysia Terengganu 21030 Kuala Terengganu, Terengganu Darul Iman Malaysia

N. Mohd Tahir*

School of Marine Science and Environment

Universiti Malaysia Terengganu

21030 Kuala Terengganu, Terengganu Darul Iman Malaysia

*Corresponding author; email: hayati@umt.edu.my

Received: 26 September 2014

Accepted: 15 February 2015 